\title{
Sürdürülebilir Aile İşletmesi Modeli: Uygulanabilirliği Üzerine Bir Araştırma*
}

\section{Sustainable Family Business Model: A Research on Applicability}

\author{
F. Zeynep Ekim İbiş ${ }^{1} \oplus$, Ayşegül İpek ${ }^{2}$ ๑ \\ ${ }^{1}$ Yüksek Lisans Öğrencisi, Bursa Uludağ Üniversitesi, Bursa, Türkiye \\ ${ }^{2}$ Öğr. Gör. Dr., Uludağ Üniversitesi Orhaneli Meslek Yüksek Okulu, Bursa, Türkiye \\ ORCID: F.Z.E.İ. 0000-0002-3839-4143; A.İ. 0000-0002-5743-6169
}

\section{ÖZ}

İşletmelerin ekonomiye yapacakları katkı düzeyi sahip oldukları yapılarıyla ilgilidir. Kurumsal olmayı başarabilmiş işletmelerin daha karlı ve dolayısıyla ekonomiye katkısının önemli ölçüde daha yüksek olduğu bilinmektedir. Türkiye'deki işletmelerin büyük çoğunluğu aile işletmelerinden oluşmaktadır. Bu işletmelerin bir kısmı kurumsallaşmayı başarırken, büyük çoğunluğu kurumsal düzeye erişememektedir. Bu çalışmada DOSAB (Demirtaş Organize Sanayi Bölgesi) ve NOSAB’ta (Nilüfer Organize Sanayi Bölgesi) bulunan aile işletmelerine 15 sorudan oluşan bir anket uygulanarak işletmelerin sürdürülebilirlik ve kurumsal yapılarıyla ilgili veri toplanmış, kurumsallaşmanın önündeki darboğazlar tespit edilmeye çalışılmıştır. Veriler SPSS 23 paket programı kullanılarak frekans analizine tabi tutulmuştur. Çalışmadan elde edilen en önemli sonuç kurumsallaşmayı engelleyen en belirleyici etkenin karar alma süreçlerinde aile değerlerinin ön planda tutuluyor olmasıdır.

Anahtar kelimeler: Aile işletmesi, kurumsallık, sistem yaklaşımı, sürdürülebilirlik

\section{ABSTRACT}

The contribution of corporations to the overall economy depends upon their institutional structure. Itis a well-known fact that the contributions of corporations which managed to be institutionalized is significantly higher. In Turkey, many corporations take the form of family corporations. Some managed to be institutionalized, yet others fall short of reaching an institutional structure. In this study, a survey consists of 15 questions applied to family corporations at DOSAB (Demirtaş Organized Industrial Site) and NOSAB (Nilüfer Organized Industrial Site) to collect data about the institutional structure and sustainability of family corporations. Data was analyzed through frequency analysis by employing SPSS 23 . The most outstanding finding of the study was that the family values' effect on the decision-making process constituted the main bottleneck factor preventing institutionalization of a corporation. Keywords: Family corporation, institutionalism, system approach, sustainability

\section{Giriş}

Aile işletmeleri, yönetim kademelerinde aile üyelerinin çalıştığ 1 , görev aldığ 1 işletmelerdir. Aile işletmeleri ile aile işletmesi olmayan işletmeler birbirlerinden oldukça farklı özelliğe sahiptir. Aile işletmesi olan işletmelere kıyasla olmayan işletmelerin sermayesi, varlıkları ve fonları tamamen işletmeye ait ve işletmenin kontrolünde bulunmaktadır. Işsletme, aile içi ilişkilerden

Başvuru/Submitted: 12.01.2020 Revizyon Talebi/Revision Requested: 23.01.2020 Son Revizyon/Last Revision Received: 27.01 .2020 Kabul/Accepted: 29.01.2020 * Bu çalışma "Aile işletmelerinde sürdürülebilirlik ve Bursa ilinde bir araştırma" adlı yüksek lisans tezinden türetilmiştir.

Sorumlu yazar/Corresponding author: F. Zeynep Ekim İbiş / zeynepibis@hotmail.com

Atıf/Citation: Ibis, F.Z.E. \& Ipek, A. (2020). Sürdürülebilir aile işletmesi modeli: Uygulanabilirliği üzerine bir araştırma. Muhasebe Enstitüsü Dergisi - Journal of Accounting Institute, 62, 51-62. https://doi.org/doi.org/10.26650/MED.2020673687 
ve duygudan bağımsız bir şekilde yönetilirken, aile işletmelerinde aile içi ilişkiler ve duygu ile birlikte aileden gelen alışkanlıklar, gelenekler, ailenin ortak kültürü gibi faktörler de yer almaktadır.

Aile işletmeleri genellikle dominant (baskın) organizasyon yapılarına sahip olmakla beraber, farklı büyüklüklerde (mikro, KOBİ veya büyük işletme) ve farklı sektörlerde faaliyet gösterebilmektedir. Bir diğer deyişle aile işletmelerinin ortak bir büyüklük yapısı veya sektörü bulunmamaktadır.

Aile işletmesini diğer işletmelerden ayırt etmenin en temel göstergesi, yöneticilerin ve çalışanların, aile bağlantılarına, değerlerine, etik ve davranışlarına sahip olmaları ve bunları az ya da çok işyerinde birbirleriyle paylaşmalarıdır. Bu nedenle aileden getirilen bu unsurlar aynı anda işletme ile karışmakta ve sonuçta olası yanlış anlaşılmalar, sorunlar ve çatışmaların temelini oluşturmaktadır (Debarliey ve Janeska-Iliev, 2015:43).

Aile işletmelerinde sürdürülebilirliğin sağlanabilmesi için işletmenin dışsal faktörleri olarak tanımlanan çevresel ve sosyal sorumluluklarının bütün içsel faktörler ile sentezlenmesi, iş süreçlerinin ve karar alma mekanizmalarının da dahil edilmesi gerekmektedir. Bu açıdan kurumsallaşma olgusu, aile ve aile işletmeleri için bir sistemi ifade etmekte ve sürdürülebilirlik adına önem taşımaktadır.

Bu çalışmada aile işletmelerinde sürdürülebilirliğin sağlanması amacıyla geliştirilen Sürdürülebilir Aile İşletmesi Modeli konu alınmış, modelin uygulanabilirliği bir anket aracılığıyla Bursa ilinde faaliyet gösteren aile işletmelerinde test edilmiştir.

\section{Aile İşletmelerinde Sürdürülebilirlik}

Tagiuri ve Davis (1996) aile işletmelerinin sahip oldukları nitelikleri "çift değerli nitelikler" olarak tanımlamış ve bu niteliklerin aile işletmelerine hem avantaj hem de dezavantaj sağladığını belirtmiştir. Çift değerli niteliklerin yol açtı̆̆ olası pozitif ve negatif sonuçlar Tablo 1.2.'de izlenebilmektedir. Aile işletmelerinde yönetimin, çift değerli niteliklerin varlığını ortadan kaldırması mümkün değildir, bunlar aile işletmelerinin doğasından kaynaklanmaktadır. Aile işletmelerindeki zorluk, çift değerli niteliklerin olumlu sonuçlarını en üst düzeye çıkarmak ve olumsuz sonuçlarını en aza indirgeyecek şekilde bu nitelikleri yönetebilmektedir (Tagiuri ve Davis, 1996:199-208).

Tablo 2.1: Aile İşletmeleri Avantaj ve Dezavantajları

\begin{tabular}{|c|c|c|}
\hline DEZAVANTAJ (-) & NİTELIK & AVANTAJ (+) \\
\hline $\begin{array}{l}\text { Norm karışıklığı ve kaygı. Aile işletmesi ve } \\
\text { mülkiyeti konuları karışabilir. İş nesnelliği eksikliği }\end{array}$ & Eş zamanlı (ikame) roller & $\begin{array}{l}\text { Yüksek aile ve işletme sadakati. Hızlı ve } \\
\text { etkili karar verme. }\end{array}$ \\
\hline $\begin{array}{l}\text { Gerginlikten kaynaklanan boğulma hissi. İşe ve } \\
\text { aileye karşı öfke ve kin }\end{array}$ & Paylaşılan kimlik & $\begin{array}{c}\text { Yüksek aile ve işletme sadakati. Güçlü bir } \\
\text { görev duygusu. } \\
\text { Daha nesnel iş kararları }\end{array}$ \\
\hline $\begin{array}{l}\text { Aile üyeleri, zayıflık gösterebilir. Geçmiş hayal } \\
\text { kırıklıkları, iş etkileşimlerine duyulan güveni } \\
\text { azaltabilir. }\end{array}$ & Hayat boyu ortak geçmiş & $\begin{array}{c}\text { Akrabalar, akrabaların güçlü yanlarını } \\
\text { ortaya çıkarabilir ve zayıf yönlerini } \\
\text { tamamlayabilir. Güçlü bir temel, bir aileyi } \\
\text { sıkıntılara karşı teşvik edebilir. }\end{array}$ \\
\hline $\begin{array}{l}\text { İletişimde nesnellik eksikliği. Kızgınlık ve suçluluk } \\
\text { iş etkileşimlerini karmaşıklaştırır. Gizli düşmanlık } \\
\text { görünebilir. }\end{array}$ & $\begin{array}{l}\text { Duygusal katılım ve duygusal } \\
\text { kararsızlık }\end{array}$ & $\begin{array}{l}\text { Olumlu duyguların ifadesi sadakat yaratır } \\
\text { ve güveni arttırır. }\end{array}$ \\
\hline $\begin{array}{l}\text { İletişimi bozabilecek hassas tepkileri tetikleyebilir ve } \\
\text { çatışma koşullarını teşvik edebilir. }\end{array}$ & Özel lisan & $\begin{array}{l}\text { Daha fazla gizlilik ile daha verimli iletişim } \\
\text { kurulmasını sağlar. }\end{array}$ \\
\hline $\begin{array}{l}\text { Akrabaların fazla gergin ve kapana kısılmış } \\
\text { hissetmelerine neden olabilir. }\end{array}$ & Karşılıklı Farkındalık ve Gizlilik & $\begin{array}{l}\text { İşletmeyi, sahipleri ve aileyi destekleyen } \\
\text { geliştirilmiş iletişim ve işletme kararları. }\end{array}$ \\
\hline Akrabalar arasında şiddetli rekabet gelişebilir. & Aile İşletmesinin Anlamı & $\begin{array}{c}\text { İşletme sembolizmi çalışanlar için güçlü bì } \\
\text { görev duygusu geliştirebilir. }\end{array}$ \\
\hline
\end{tabular}


Kurumsallaşmanın, aile işletmeleri tarafından nasıl algılandığı, kurumsallaşmanın işletme ve aile için sağlayabileceği katkı düzeyi ve kurumsallaşmanın kurulabilmesi için yapılacak çalışmaların hangi aşamada ve zamanda başlanacağının belirlenmesi önem taşımaktadır. Ayrıca, aile ve işletmenin var olduğu yaşam döngüsü, ailenin ve işletmenin kendine has örgüt yapısı, sahip oldukları kültür, inanç ve değerler, aile ve işletme üzerinde etkisi olan iç ve dış faktörler gibi birçok ölçüt kurumsallaşmanın algılanması ve uygulanmasında farklılıkların görülmesine de neden olmaktadır.

Aile işletmelerinde sürdürülebilirlik, gelecek nesillerin ihtiyaçlarını karşılayabilme yeteneğinden ödün vermeden, işletmenin sürdürülebilirliğini sağlaması olarak tanımlanabilmektedir. Aile işletmelerinin hem işletmenin hem de ailenin ihtiyaçlarına hizmet edecek bir şekilde nesiller boyunca sürdürülebilirliği sağlamak için bir aile yönetişimi yaklaşımını benimsemesi ve işletmeye özgü "sürdürülebilir aile işletmesi modeli” tasarlaması önem taşımaktadır.

Çok jenerasyonlu aile işletmelerinde aile karmaşıklı̆̆ sürdürülebilirliği tehdit eden önemli unsurlardan biridir. Aile karmaşıklığı, belirli bir zamanda yaşayan nesil sayısının artması ile aile işletmesinde çalışan aile üyelerinin sayısının artması ve aralarındaki ilişkilerin türünün karmaşıklaşması olarak tanımlanmaktadır. Karmaşıklık derecesi, işletmeye katılan aile üyelerinin / kuşakların sayısına göre belirlenir. Bu karmaşıklıklar nedeniyle, aile işletmesindeki iş süreçleri karmaşıklaşır ve çoğu zaman liderlik yetkilendirmesi ve işletmenin stratejik geleceği konusunda anlaşmazlıklar ile sonuçlanır (Ward, 1997:323-338).

Aile işletmeleri, kendine özgü bir içeriği temsil etmesi bakımından aile işletmesi olmayan işletmelerden farklı özellikler taşımaktadır. Aile üyeleri arasında var olan karmaşık dinamikler sadece aile işletmelerinin performansını etkilemekle kalmaz aynı zamanda büyümesi, değişmesi ve zaman içinde geçişini de etkiler (Venter vd., 2012: 71).

Aile işletmeler ve aile işletmesi olmayan işletmeleri sürdürülebilirliği etkileyen farklılıkları aşağıdaki tabloda izlenebilmektedir (Strike, 2013:295).

Tablo 2.2: Aile İşletmesi ve Aile İşletmesi Olmayan İşletmelerin Sürdürülebilirliğini Etkileyen Farklılıklar

\begin{tabular}{|c|c|c|}
\hline Boyutlar & Aile işletmeleri & Aile işletmesi olmayan işletmeler \\
\hline Doğa & Duygusal & Ak1lc1 \\
\hline Üyelik & İstemsiz & Gönüllü \\
\hline Değerlendirme & Sadakat ve karşılıklılık normlarına dayalı & İşletmeye olan katkılarına dayalı \\
\hline Amaç & $\begin{array}{c}\text { Üyeleri korumak, beslemek ve geliştirmek için } \\
\text { içeriye dönük }\end{array}$ & Kar amaçlı \\
\hline Değişime eğilim & $\begin{array}{l}\text { Değişim ailenin güvenliği açısından bir tehdit } \\
\text { olarak görülür. }\end{array}$ & $\begin{array}{c}\text { Değişim büyüme ve gelişme için bir firsat olarak } \\
\text { görülür }\end{array}$ \\
\hline
\end{tabular}

Bir aile işletmesinin, nesilden nesile sürdürülebilir bir şekilde büyümesini sağlamak için işletme yönetimini basit ama kapsamlı bir araçla güçlendirmeye ihtiyaç vardır. Kurucu neslin ötesinde sürdürülebilirliği sağlamak için bir aile işletmesiyle ilgili benzersiz zorluklar göz önüne alındığında, sürdürülebilirlik konusunun aile işletmelerinde farklı bir anlam taşıdığını görülmektedir (Ungerer ve Mienie, 2018:2).

Çok jenerasyonlu aile işletmelerinde başarı ve sürdürülebilirliğe yardımcı olacak faktörler şu şekilde sıralanabilmektedir (Oudah vd., 2018:4).

- Başarı planlaması: Kurucunun halefine inisiyatif verme yeteneği/isteğine sahip olması

- Stratejik planlama : Aile ile ilgili konular ve amaçların sürdürülebilirliği konusunda ailenin fikir birliği

- Kurumsal yönetim: Karar alma ve problem çözme yapılanmasının planlanması

- Liderlik: Yetkili aile üyesi liderliğinin benimsenmesi ve etkin liderlik becerilerine sahip olunması

- Aile işletmesi değerleri: Aile normları ve işletme normlarının birlikte sürdürülebilirliğinin sağlanması

- Aile sermayesi: İnsan sermayesi ve sosyal sermayeye önem verilmesi

- Aile işletmesi danışmanları: Çatışmaların çözümünde formal ve informal danışmanlık hizmetlerinin alınması 
$\mathrm{Bu}$ faktörler, aslında, işletme ile aile arasında gerekli dengeyi sağlama ve kazanma ile ilgilidir. Çatışmaların nasıl ele alındığı, aile üyelerinin yönetimdeki rolleri ve beklenmedik durumlar, uzun vadeli hedefler aile işletmelerinin sürdürülebilirlik planlarında yerine almalıdır. Aile üyelerinin sayısı arttıkça, transfer sürecinde potansiyel komplikasyonların olasılığı daha fazladır. Aile işletmelerini sürdürmek ve duygusal çatışmaları azaltmak için güçlü bir kurumsal yönetişime ve aile yönetişimine ihtiyaç duyulduğunu açıktır.

Aile işletmelerinin yaklaşık üçte biri ikinci nesilde hayatta kaldığ 1 ve ancak yalnızca yüzde 10-15’i üçüncü nesle ulaştığ pek çok araştırmacı tarafından dile getirilmiştir. Aile işletmelerinin büyük ölçüde planlama zayıflığı nedeniyle ilk kuşağın ötesinde hayatta kalamaması ciddi ekonomik sorunlara yol açabilmektedir (Briley,1986:36-43; Le Breton-Miller, 2004, 305328; Daspit vd., 2016:44-64).

\section{Sürdürülebilir Aile İşletmesi Modeli}

Aile işletmelerinin dışsal faktörler olarak nitelendirilen çevresel ve sosyal sorumluluklarının, işletmenin sürdürebilirliğinin sağlanabilmesi için tüm içsel faktörlerle sentezlenerek iş süreçlerine ve karar alma mekanizmalarına dahil edilmesi gerekmektedir. Bu kapsamda aile ve aile işletmeleri açısından bir sistemi ifade eden kurumsallaşma büyük önem taşımaktadır (Yelkikalan ve Aydın, 2010:88).

Aile işletmeleri yapısı gereği kendi içerisinde farklı dinamiklere sahip olması, sadece performanslarını değil aynı zamanda işletmenin büyümesini, değişmesini ve yönetim kültürünü de etkilemektedir. Aile ve işletme arasındaki etkileşime ilişkin 1999 yılında Stattford v.d. tarafından geliştirilen Sürdürülebilir Aile İşletmesi Modeli, aile ve işletmenin sürdürülebilir başarının sağlanabilmesi noktasında sürece katkılarını ortaya koymaktır. Konuya ilişkin model aşağıda şekil 5’te yer almaktadir.

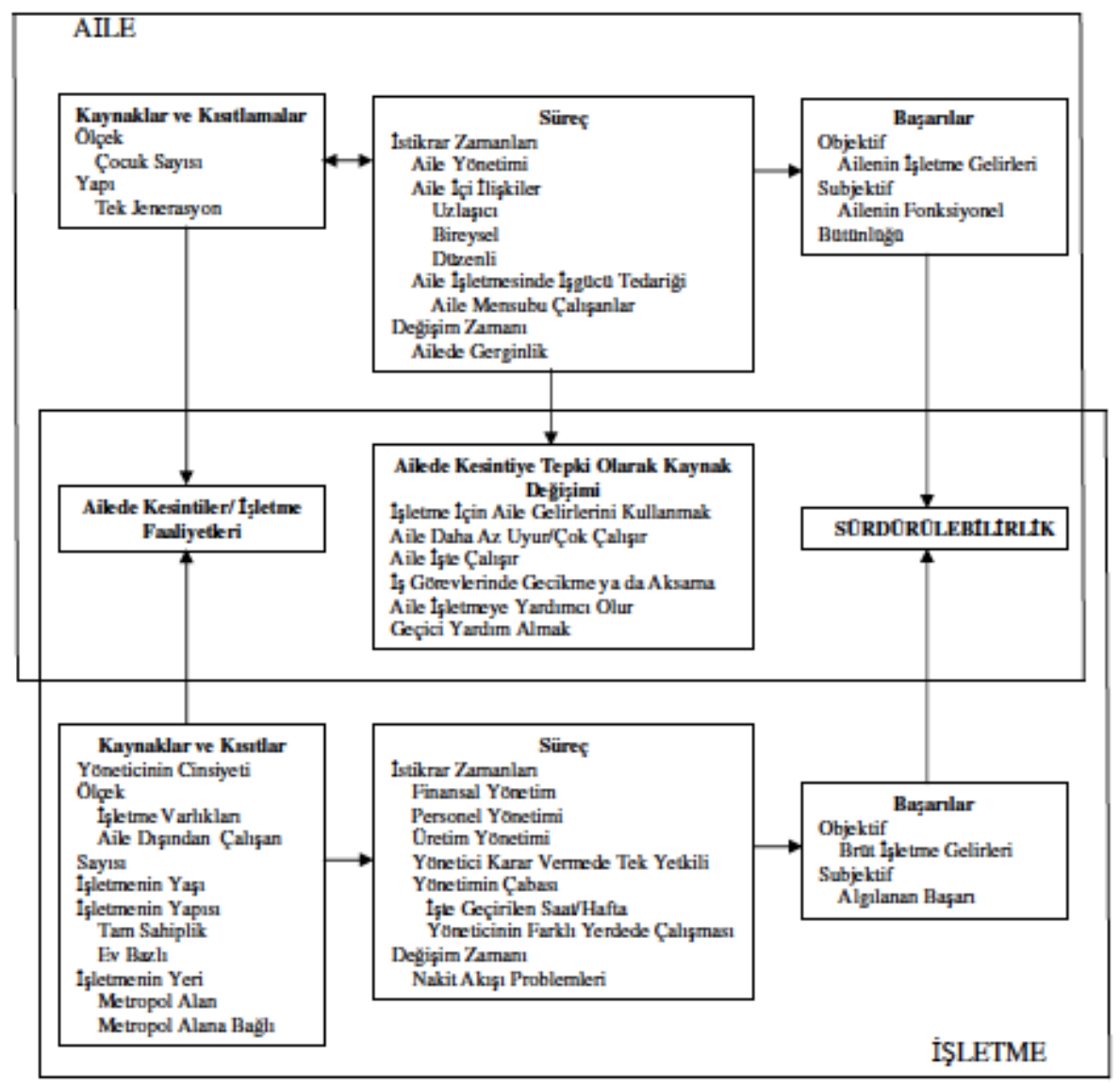

Şekil 3.1. Sürdürülebilir Aile İşletmesi Modeli

Kaynak: Stafford, Kathryn, et al. "A research model of sustainable family businesses.” Family business review 12.3 (1999): 197-208. 
Aile işletmeleri, doğası gereği, sahip olunan aile içindeki dinamikler nedeniyle karmaşıktır. Sürdürülebilir aile işletmesi modeli (SFB modeli) esnek yapısı ile yalnızca işin bir parçası olan ya da yalnızca aile sisteminin bir parçası olan ve her iki sistemdeki kaynakları kullanılmasına imkan veren karmaşık süreçleri ele alır. Aile işletmesi iş sisteminin sürdürülebilirliğini bir bütün olarak vurgular ve aile ve işletme sistemlerine eşit davranır. SFB modeli, bir aile işletmesinin sürdürülebilirliğinin hem iş başarısının hem de aile işlevselliğinin bir sonucu olduğunu ifade etmektedir. Her iki sistemdeki herhangi bir birey her iki sistemin parçalarını da etkileyebilir. SFB modeli, iş girişimciliğini ailenin sosyal bağlamında konumlandırmaktadır (Olson vd., 2003:643)

SFB modelinin ana noktası, aile ve işletmenin alt sistemleri oluşturmaktadır. Bu model ile iki alt sisteme ilişkin farklı bileşenler, mevcut kaynaklar, işletme süreçleri ve sınırları önem taşımaktadır ve bütün bu unsurları bir araya getirmektedir. Modele göre, her bileşen karşılıklı etkileşim içinde, birbirini etkilemekte ve birbirinden etkilenmektedir. Bundan dolayı aile işletmelerinde ailenin ve işletmenin uyumlu etkileşimi ve başarısı ile sürdürülebilir başarı sağlanabilecektir (Birincioğlu ve Acuner, 2015: 500; Güleş vd., 2013: 57-58).

SFB modeli, aile işletmesi sürdürülebilirlik modeli oluşturmak için aile işlevi modeli ile aile iş başarısı modelini eşleştirmektedir. Şekil 5'de gösterilen modelin odağı, aile işletmesinin sürdürülebilirliği, aile kazanımlarının bir fonksiyonu ve aile ile iş arasındaki ticari kazanımlar ve işlemlerdir. Aynı zamanda, işletmesinden az ya da çok bağımsız olarak gerçekleştiği düşünülebilecek aile kaynakları ve kısıtlamaları (hem aile yapısını hem de aile süreçlerini içerecek şekilde) tanımlanmıştır. Aynı şekilde, aileden bağımsız olmayan ticari kaynaklar, kısıtlamalar ve süreçler bulunmaktadır. Şekilde soldan sağa hareket ederken, karakteristik veya işlemlerden herhangi biri sola veya üst veya alt sıradaki herhangi bir işlem sağa veya merkeze etki edebilir. Bu modelin genel amacı, aile ve işletme kaynaklarını ve iş ve aile başarısına ve sürdürülebilir aile işletmelerine yol açması muhtemel kısıtlamaları, süreçleri ve işlemleri tanımlamaktır.

\section{SFB Modelinin Uygulanabilirliği}

\subsection{Metodoloji}

SFB modelinin uygulanabilirliği, modelin içinde yer alan unsurlardan ve parametrelerden oluşan bir ölçek geliştirmek suretiyle Bursa'da Demirtaş ve Nilüfer Organize Sanayi Bölgesi’nde faaliyet gösteren aile şirketlerinde test edilmiştir.

Ölçek, tanımlayıcı istatistiklere yönelik on bir adet açık uçlu soru, aile şirketlerindeki değer alglarının ölçüldüğü 5 adet 5 'li Likert'li soru, aile odaklı amaçların ölçüldüğü sıralama soruları, aile şirketlerindeki mekanizmaların olup olmadığını ölçen 9 adet evet/hayır sorusu ve aile içindeki gerilime sebep olma derecesini ölçen 6 adet 5'li Likert'li sorudan oluşmaktadır.

Anket soruları, Bursa'da DOSAB (Demirtaş Organize Sanayi Bölgesi) ve NOSAB (Nilüfer Organize Sanayi Bölgesi)'da faaliyet gösteren 102 aile şirketine mail yoluyla ulaştırılmış, 79 tanesinden geri dönüş sağlanmıştır. 79 anketin 4 adedi eksik cevaplandığından kapsam dışı tutulmuş ve toplamda 75 anket değerlendirilmiştir. Dolayısıyla araştırmanın evrenini, Bursa'da faaliyet gösteren 75 aile şirketi oluşturmaktadır.

\subsection{Verilerin Analizi ve Elde Edilen Bulgular}

Tablo 4.1.'den de görüldüğü üzere, araştırmaya katılan aile şirketlerinin faaliyet gösterdiği sektörler elektrik, gaz ve su, imalat, gayrimenkul faaliyeti, holding, inşaat ve bayındırlık, toptan ve perakende ticaret, otel ve lokantalar, madencilik, tarım, orman ve balıkçılık olmak üzere toplam sekiz grupta toplanmıştır. Sektör grupları Kamuyu Aydınlatma Platformu (KAP)'taki başlıklar dikkate alınarak oluşturulmuştur. 


\begin{tabular}{|l|c|c|}
\hline Tablo 4.1: Aile Şirketlerinin Faaliyet Gösterdiği Sektörler & \multicolumn{2}{|c|}{ \% } \\
\hline Şirketin Faaliyet Gösterdiği Sektör & 5 & 6,67 \\
\hline Elektrik, Gaz ve Su & 50 & 2,67 \\
\hline İmalat & 2 & 9,33 \\
\hline Gayrimenkul faaliyeti & 7 & 4 \\
\hline Holding & 3 & 5,33 \\
\hline İnşaat ve bayındırlık & 4 & 2,67 \\
\hline Toptan ve perakende ticaret, otel ve lokantalar & 2 & 2,67 \\
\hline Madencilik & 2 & 100 \\
\hline Tarım, Orman, Balıkçılık & 75 & \\
\hline TOPLAM & & \\
\hline
\end{tabular}

Araştırmaya katılan aile şirketlerinin çoğunluğunun $(\% 66,67)$ faaliyet gösterdiği sektör, imalat sektörüdür. Bunu sırasıyla $\% 9,33$ ile holdingler, \%6,67 ile elektrik, gaz ve su sektörü, \%5,33 ile toptan ve perakende ticaret, otel ve lokantalar, \%4 ile inşaat ve bayındırlık sektörü takip etmektedir. Araştırmaya katılan aile şirketlerinin en az faaliyet gösterdiği sektörler ise aynı yüzdeye sahip $(\% 2,67)$ gayrimenkul faaliyeti, madencilik ve tarım, orman, balıkçılık sektörleridir.

Araştırmaya katılan aile şirketlerinin çalışan sayıları 2005 tarihli 25997 sayılı Resmî Gazete 'de yayımlanan Küçük ve Orta Büyüklükteki İşletmelerin Tanımı, Nitelikleri ve Sınıflandırılması Hakkında Yönetmelik’e göre oluşturulmuştur. Buna göre, 10'dan az çalışanı olan küçük işletmeler mikro işletme, 10 ila 50 arasında çalışanı olan şirketler küçük işletme, 51 ila 250 arasında çalışanı olan işletmeler orta büyüklükteki işletme, 250'den daha fazla çalışanı olan işletmeler ise büyük işletme sayılmaktadır. Araştırmaya katılan aile şirketlerinin büyüklükleri Tablo 4.2.'de yer almaktadır.

\begin{tabular}{|l|c|c|c|}
\hline Tablo 4.2: Aile Şirketlerinin Çalışan Sayıları ve İşletme Büyüklükleri & Sayı & $\%$ \\
\hline Çalışan Sayıları & İşletme Büyüklüğü & 2 & 2,67 \\
\hline$<10$ & Mikro & 24 & 32 \\
\hline 10 ila 50 & Küçük & 24 & 32 \\
\hline 51 ila 250 & Orta & 25 & 33,33 \\
\hline $250<$ & Büyük & 75 & 100 \\
\hline TOPLAM & & & \\
\hline
\end{tabular}

Ankete katılan aile şirketlerindeki yönetim kurulu sayısı ortalama beş kişi olarak belirlenmiştir. Aynı zamanda bu yönetim kurulu üyelerinin hepsinin aile üyesi olduğu saptanmış birkaç şirket dişında yönetim kurulunda bağımsız üyeye yer verilmediği görülmüştür. Ancak yönetim kurulu üyeliği dışında şirket ile ve aile ile hiçbir bağı bulunmayan bu üyeler şirkete bağımsız, saygılı ama eleştirel bir bakış açısı getirmektedirler.

Aile anayasası, aile işletmelerinin sürekliliğini etkileyecek ana konuları içeren bir belgedir. Aile anayasası, aile üyelerinin hem birbirleriyle olan ilişkilerini hem de kendileriyle iş arasındaki ilişkileri en iyi, en doğru bir biçimde yönetebilmelerini sağlayacak temel ilkeleri yerine getirmede rehber olacaktır. Aile Konseyinin temel amacı ise aile üyelerinin değerlerini, gereksinimlerini ve işletmeden beklentilerini göz önünde bulundurarak, aynı zamanda işletmede çalışmayan aile üyelerine de fikirlerini paylaşma olanağı sağlamak için ortam yaratmaktadır ve tüm bu oluşumlar şirketin başarısı için önemli bir unsurdur ve modelimizde de görüldüğü gibi başarı, sürdürülebilirliği beraberinde getirmektedir. Anket sonuçlarına göre, araştırmaya katılan şirketlerin \%73,3'ünde aile anayasası bulunmamakta, \%60’ında ise aile konseyi toplantılarının yapılmadığı sonucuna varılmaktadır. Bu istatistikler, SFB modelinin ana noktasını oluşturan iş-aile dinamizmine uyum sağlamamaktadır. Sürdürülebilir bir aile işletmesi için aile anayasasının oluşturulması ve destekleyici aile konseyi toplantılarının düzenlenmesi vazgeçilmez bir unsurdur.

Aile işletmelerinin başarı ve sürdürebilirliği sağlama koşullarından biriside, işletmede çalışan aile üyeleri ile aile üyesi olmayan çalışanlar arasındaki ücretlendirme politikasıdır. Bu durum aile üyesi olmayan çalışanların motivasyonu açısından 
önemli bir değerdir. Yaptığımız ankette, işletmelerin yüzde \%60'ında ayrı bir ücretlendirme politikası olduğunu ve aile üyelerinin daha fazla ücret aldığını tespit edilmiştir. Fakat bu durum aile dışı çalışanları olumsuz yönde etkileyecek, motivasyonunu düşürecek bu ister istemez iş performansına yansıyacaktır. Bu durum şirket büyüdükçe ve kurumsallaştıkça değişmekte ve aynı ücretlendirme politikasının uygulandığı görülmektedir. Aile üyesi çalışanlar için ayrı bir ücretlendirmek politikası bulunması SFB modelinin uygulanması açısından negatif bir unsurdur.

Aile işletmelerinin ileriki dönemlerde karşılaştığı en büyük problemlerden biride girişimcinin emekliliği, ani kaybı gibi durumlarda, girişimciden sonra onun yerine geçecek ve işletmeye liderlik edecek varisin belirlenmesi ile ilgili yapılacak çalışmaların ve planların olup olmadığı ile ilgilidir. Bu süreci en etkin ve sağlıklı bir şekilde yürütmek işletmenin sürdürülebilirliği açısından büyük önem taşımaktadır. Fakat yapılan anket çalışmasında görüldüğü gibi aile işletmelerinin yüzde \%64'ünde genç ve çocuk aile üyeleri ile ilgili bir kariyer planlamasının yapılmıyor olmasıdır. Bunun en önemli sebeplerinden biri bugünün gençleri ve çocuklarını oluşturan $Y$ ve $Z$ kuşağının daha özgür düşünen, mutlu olacağı işi yapmayı tercih eden bir neslin geliyor olması olarak açıklanabilir, ancak bu durum işletmenin sürdürülebilirliği açısından sıkıntı yaratabilmektedir. Bu konu ile ilgili girişimci aile büyüğünün zaman zaman yeni nesile işletmenin havasını teneffüs ettirmeleri bu ortamdan çok uzak büyümemelerini sağlamaları gerekmektedir. Kariyer planlamasının aile şirketlerinde yapılmaması SFB modelinde kaynakların modele doğru olarak girmemesine yol açmaktadır.

Anket çalışmasında, işletme bünyesinde çalışmayan aile üyelerinin (eş, çocuk vb.) işile ilgili bilgilendirilip bilgilendirilmediği sorulduğunda ise \%38'inin bilgilendirdiği \%12'sinin ise kısmen bilgilendirdiği görülmüştür. İşletmenin sürdürülebilirliği açısından baktığımızda bilgilendirmenin doğruluğu kaçınılmazdır. İşletmenin özellikle mali durumunu bilmek, örneğin bir kriz anında ya da yatırım durumunda işletmenin likiditesinin önemli zamanlarda, ailenin desteği, girişimciyi rahatlatacak ve işletmeye destek olacaktır. Diğer yandan, aile içi bilgilendirmenin yapılması, işletmeye olan aidiyet duygusunu arttıracaktır.

\begin{tabular}{|c|c|c|c|c|c|c|c|c|c|c|}
\hline & \multicolumn{2}{|c|}{$\begin{array}{c}\text { Kesinlikle } \\
\text { katılıyorum }\end{array}$} & \multicolumn{2}{|c|}{ Katılıyorum } & \multicolumn{2}{|c|}{ Kararsizım } & \multicolumn{2}{|c|}{ Katılmıyorum } & \multicolumn{2}{|c|}{$\begin{array}{c}\text { Kesinlikle } \\
\text { katılmıyorum }\end{array}$} \\
\hline & $\mathbf{F}$ & $\%$ & $\mathbf{F}$ & $\%$ & $\mathbf{F}$ & $\%$ & $\mathbf{F}$ & $\%$ & $\mathbf{F}$ & $\%$ \\
\hline $\begin{array}{l}\text { Şirket faaliyetlerinin } \\
\text { yürütülmesinde aile değerlerinin } \\
\text { önemli bir etkisi vardır. }\end{array}$ & 43 & 57,3 & 32 & 42,6 & - & - & - & - & - & - \\
\hline $\begin{array}{l}\text { Aile şirketimizde çalışanlar } \\
\text { yöneticiler için değil, yöneticiler } \\
\text { ile birlikte çalıştıklarını } \\
\text { hissederler. }\end{array}$ & 42 & 56 & 27 & 36 & - & - & 6 & 8 & - & - \\
\hline $\begin{array}{l}\text { Çalışanların başarısı şirketin } \\
\text { başarısıdır. }\end{array}$ & 48 & 64 & 23 & 30,6 & 4 & 5,3 & - & - & - & - \\
\hline Şirketin başarısı ailenin başarısıdır. & 35 & 46,6 & 26 & 34,6 & 10 & 13,3 & 4 & 5,3 & - & - \\
\hline $\begin{array}{l}\text { Aile şirketimizde çalışanlar } \\
\text { sadece bir çalışan olmaktan } \\
\text { ziyade şirketin sahibiymiş gibi } \\
\text { hissederler. }\end{array}$ & 14 & 18,6 & 27 & 36 & 20 & 26,6 & 4 & 5,3 & 10 & 13,3 \\
\hline
\end{tabular}

Aile işletmelerinde Tablo 4.3.'de de yer aldı̆̆g üzere değer algıları ile ilgili sorularında, aile işletmelerinin büyük çoğunluğu, şirket faaliyetlerinin yürütülmesinde aile değerlerinin büyük bir etkisi olduğuna, işletmede aile üyesi olmayan çalışanların, yöneticiler için değil, yöneticilerle birlikte işletme için çalıştıklarını ve çalışanların başarısının, şirketin başarısı olduğu fikrine katılmaktadır. Bütün bu algılar işletmenin büyüme gelişme ve evrelerinde çok önemli değerlerdir. Tüm bu değerler işletmeye başarıyı ve beraberinde sürdürülebilirliği getirir. İşletmenin başarısı, ailenin başarısı mıdır diye sorduğumuzda ankete katılan girişimcilerin büyük çoğunluğu buna olumlu yanıt vermiştir. Aile üyeleri açısından işletmenin ismi ve prestiji, ailenin ismi ve prestiji ile aynı anlamda düşünülür dolayısıyla şirketin başarısı aynı zamanda ailenin başarısıdır. Bu veriler SFB modelinin uygulanabilirliği açısından olumlu göstergelerdir aile ve işletmeyi bir sistem içerisinde kabul eden 
SFB modeli, ancak iki olgunun dengeli bir biçimde yönetilmesi durumunda başarıya ulaşabilmektedir.

Aile işletmelerinde başarıyı dolayısıyla sürdürülebilirliği etkileyen bir başka faktör de çalışanların kendilerini şirketin sahibi gibi hissetmeleri ve her iki tarafında ortak amaçlar için çalışmalarıdır. İşletmede aile üyesi olmayan çalışanların, işletmeyi benimseyip sahiplenmesi motivasyonu beraberinde getirir. Girişimcinin bu konuyu önemsemesi ve bu konuda uygun ortamı yaratması gerekir. Günlük hayatlarının neredeyse üçte birini geçirdikleri işyerleri, çalışanlar için önemli bir ortamdır. Motivasyonu yüksek olan bireyler daha istekli ve verimli çalışırlar ve işlerine olan bağlılıkları o oranda artar, yapmış oldukları işten sosyal ve psikolojik doyum sağlarlar. Ankete katılan işletmelerin birçoğu çalışanlarının böyle hissettiklerini belirtmişlerdir \%18,6 gibi bir oranda işletme ise buna katılmamıştır. Çalışanların işletmeyi benimsemesi SFB modelinin önemli ve pozitif girdilerinden biridir.

\begin{tabular}{|c|c|c|}
\hline ŞİRKETE AİT MEKANIZMALAR & EVET & HAYIR \\
\hline Resmi danışma kurulu (bir danışman grubuyla düzenli toplantılar) & 55 & 20 \\
\hline Resmi olmayan danışma kurulu (danışmanlarla özel toplantılar) & 33 & 42 \\
\hline İşletme yönetimi ekibi & 23 & 52 \\
\hline Bağımsız yönetim kurulu değerlendirmesi (dış kaynak tarafından) & 49 & 26 \\
\hline Yönetim kurulunun öz değerlendirmesi & 26 & 49 \\
\hline Finansal tabloların bağımsız dış denetimi & 37 & 38 \\
\hline Aile dışı çalışanların seçimi, ücretlendirilmesi ve desteklenmesi için bir politika & 23 & 52 \\
\hline Aile çalışanlarının seçimi, ücretlendirilmesi ve tanıtımına yönelik politika & 35 & 40 \\
\hline İşle ilgili konularda ilgili taraflara formel raporlama sistemi (bilgilendirme) & 31 & 44 \\
\hline
\end{tabular}

Tablo 4.4.'de aile şirketlerindeki mekanizmalara ilişkin sonuçlar yer almaktadır. Aile işletmelerine ait mekanizmalarla ilgili yöneltilen sorulardan elde edilen verilere göre, şirketin başarısını doğrudan etkileyen en önemli üç mekanizmaya hayır cevabı verilmiştir. Yani işletmelerin hem aile bireyi olan hem de dışarıdan gelen çalışanların seçimi, ücretlendirilmesi ve desteklenmesine yönelik bir politikalarının olmadığı görülmüştür. Fakat bir işletmenin bu politikalarının olması sağlıklı bir şekilde işlemesi işletmenin kurumsallaşması açısından önem arz etmektedir. SFB modelinin aile süreçlerinde yer alan bu parametreler sürdürülebilirlik açısından önemli politikalardır. Bu politikaların yokluğu örneklemdeki şirketlerin sürdürülebilirliği açısından sorun olarak anlamlandırılmaktadır.

\begin{tabular}{|c|c|c|c|c|c|c|c|c|c|c|}
\hline & \multicolumn{2}{|c|}{$\begin{array}{l}\text { Gerilime neden } \\
\text { olmaz }\end{array}$} & \multicolumn{2}{|c|}{$\begin{array}{l}\text { Biraz gerilime } \\
\text { neden olur }\end{array}$} & \multicolumn{2}{|c|}{$\begin{array}{c}\text { Gerilime neden } \\
\text { olur }\end{array}$} & \multicolumn{2}{|c|}{$\begin{array}{l}\text { Fazla gerilime } \\
\text { neden olur }\end{array}$} & \multicolumn{2}{|c|}{$\begin{array}{l}\text { Çok büyük } \\
\text { gerilime neden } \\
\text { olur }\end{array}$} \\
\hline & $\mathbf{F}$ & $\%$ & $\mathbf{F}$ & $\%$ & $\mathbf{F}$ & $\%$ & $\mathbf{F}$ & $\%$ & $\mathbf{F}$ & $\%$ \\
\hline $\begin{array}{l}\text { Kimin ne iş yapacağı } 1 \\
\text { hakkında aile üyeleri arasında } \\
\text { fikir ayrıllığ } 1\end{array}$ & 40 & 53,3 & 21 & 28 & 8 & 10,7 & 6 & 8 & - & - \\
\hline $\begin{array}{l}\text { Karar alma konusunda kimin } \\
\text { yetkili olacağı hakkında aile } \\
\text { üyeleri arasında fikir ayrılığ } 1\end{array}$ & 47 & 62,7 & 10 & 13,3 & 11 & 14,7 & 4 & 5,3 & 3 & 4 \\
\hline $\begin{array}{l}\text { Aile üyelerinin şirkette eşit } \\
\text { pay sahibi olmamaları }\end{array}$ & 42 & 56 & 19 & 25,3 & 8 & 10,7 & - & - & 6 & 8 \\
\hline $\begin{array}{l}\text { Aile üyelerinin } \\
\text { ücretlendirilmesinde } \\
\text { adaletsizlik }\end{array}$ & 31 & 41,3 & 6 & 8 & 25 & 33,3 & 3 & 4 & 10 & 13,3 \\
\hline $\begin{array}{l}\text { Şirket ile ilgili çatışmaları } \\
\text { çözümlemekte başarısızlık }\end{array}$ & 25 & 33,3 & 19 & 25,3 & 16 & 21,3 & 9 & 12 & 6 & 8 \\
\hline $\begin{array}{l}\text { Aile üyelerinin iş yükü } \\
\text { konusunda adaletsizlik }\end{array}$ & 38 & 50,7 & 15 & 20 & 13 & 17,3 & 9 & 12 & - & - \\
\hline
\end{tabular}


Aile şirketleri doğaları gereği yapılarında duygusallık barındırmaktadır. Bu açıdan bilinen kurumsal yönetim uygulamalarını aile şirketlerine adapte etmek çok kolay olmamaktadır. Bu devrede aile yönetişimi devreye girmektedir. Bu yapıdan beklenen, geleneksel aile dinamikleriyle yıpratılmamış rasyonel ve ekonomik aile kararlarıdır. Bunun doğru bir şekilde uygulanmadığı aile işletmelerinde bir takım şirket içi çatışmaların yaşanılması kaçınılmaz bir gerçektir. Yapılan anket çalışmasında Tablo 4.5'de görüldüğü üzere aile üyelerinin ücretlendirilmesindeki adaletsizliğin, şirket içindeki çatışmaları çözümlemekteki başarısızlığın, aile üyelerinin eşit pay sahibi olmamasının, karar alma konusunda kimin yetkili olacağ 1 konusunda aile üyeleri arasında fikir ayrılıkları yaşanması şirket içi çatışmalar sebep olduğu gözlenmiştir. Dolayısıyla bu çatışmalar şirketleri ister istemez bir takım maddi ve manevi kriz yaşamalarına sebep olabilmektedir. Dolayısıyla doğru bir aile yönetişimi yapısını oluşturmak bu tarz çatışmaların meydana gelmesini engelleyecektir.

\section{Sonuç}

Türkiye'deki şirketlerin çoğunluğunu oluşturan aile şirketleri hem ekonomiye büyük katkı sağlamakta hem de toplum geleneklerine bağlı yapıların korunması yönünde sosyal katkı sağlamaktadır. Aile şirketlerine diğer şirketlerden ayıran en önemli özellik yönetim kademelerinde duygusallığa fazlasıyla önem verilmesi atama ve ücretlendirme politikalarına aile içi ilişkilerin etki etmesidir. Aile içi çatışmalar çoğu zaman aile şirketlerinin sürdürülebilirliğe olumsuz etki yapmaktadır.

Ülkemizdeki toplumsal yapı göz önüne alındığında aile şirketlerinin ekonomideki yerinin bozulmadan devam edeceği gözlemlenmektedir. Bu açıdan aile şirketlerinin sürdürülebilirliği konusunda yapılan ve yapılacak olan çalışmalar literatüre katkı yanında uygulama alanına da katkı sağlamaktadır.

Aile şirketlerinin karışık dinamiklere sahip olan doğası (Olson vd. 2003) tarafından geliştirilen sürdürülebilir aile işletmesi modeli sayesinde karakterize edilebilmektedir. Geliştirilen bu modelin ana noktasını sürdürülebilirlik oluştururken aile ve işletmeye dair kaynaklar ve kısıtlamalar süreçler ve başarılar eş zamanlı olarak sürece katkı sağlamaktadır. Model içerisinde yer alan bileşenler birbirleriyle karşılıklı etkileşim halindedir. Aile ve şirketin birbiriyle uyumlu etkileşimi ve başarısı aile şirketlerinde sürdürülebilirliği sağlayacaktır.

Çalışmada sürdürülebilir aile işletmesi modelini Bursa ilinde NOSAB ve DOSAB' ta yer alan 75 aile şirketinde bulunup bulunmadığı test edilmiştir. Uygulama aile işletmelerinde SFB modelinin uygulanabilirliğini test etme niteliğini taşırken araştırmanın kısıtı ankete katılım konusundaki isteksizliktir. Aile içi değerlerin paylaşılma konusundaki isteksizlik bu konuda göz çarpmaktadır. İleriki çalışma olarak daha geniş bir örneklemde anket uygulamasının yapılması ve sürdürülebilir aile işletmesi modelini içermeyen aile şirketlerine modelin kurulması konusunda destek sağlanması önerilebilmektedir.

Ankette yer alan sonuçlar bir bütün olarak değerlendirildiğinde SFB modelinin örneklemdeki şirketlerde uygulanabilirliğini olumsuz yönde etkileyebilecek olan bulgular;

- Çoğunluk şirkette aile anayasasının bulunmaması

- Çoğunluk şirkette aile konseyi toplantılarının yapılmaması

- Aile içi bilgilendirme toplantılarına önem verilmemesi

- Aile üyesi çalışanlar için ayrı bir ücretlendirme politikasının bulunması

- Aile üyelerine yönelik kariyer planlaması yapılmaması

- Diğer yandan SFB modelinin örneklemdeki şirketlerde uygulanabilirliğini olumlu yönde etkileyecek faktörler aile üyeleri açısından ailenin ismi ve prestiji ile işletmenin ismi ve prestijinin aynı anlamda düşünülmesi ve aile işletmesi çalışanlarının işletmeyi benimsemesi olarak belirlenmiştir.

Söz konusu olumsuz faktörlerin aile işletmeleri tarafından ortadan kaldırılarak SFB modelinin işletmelerde uygulanabilir kılmak, aile işletmelerinin sürdürülebilirliğinin sağlaması yönünde önemli bir adım olacaktır. 
Nesiller boyu sürdürülebilirliği sağlayacak olan planlamanın kilit unsuru, sosyal ilişkiler, bilgi ve beceri alışverişi anlamında insan sermayesinin gelişimidir. Aile işletmesinin sürdürülebilirliğini sağlamak için planlama yapılmak suretiyle yönetimin bir nesilden haleflere devredilmesi koordine edilmelidir.

Hakem Değerlendirmesi: Dış bağımsız.

Çıkar Çatışması: Yazarlar çıkar çatışması bildirmemiştir

Finansal Destek: Yazarlar bu çalışma için finansal destek almadığını beyan etmiştir.

Peer-review: Externally peer-reviewed.

Conflict of Interest: The authors has no conflict of interest to declare.

Grant Support: The authors declared that this study has received no financial support.

\section{Kaynakça}

Alayoğlu N. (2003). Aile işletmelerinde yönetim ve kurumsallaşma. İstanbul: Müsiad Yayınları.

Anderson R. C., \& Reeb D. M. (2004). Board composition: Balancing family influence in S\&P 500 firms. Administrative Science Quarterly, 49, 209-237.

Aronoff C. E., \& Ward J. L. (2000). Family business values. Family business leadership series, 12(17).

Arteaga R., \& Menéndez-Requejo S. (2017). Family constitution and business performance: moderating, family. Business Review, 30(4), $320-338$.

Ateş Ö. (2005). Aile işletmeleri: Değişim ve süreklilik. Ankara: Ankara Sanayi Odası Yayınları.

http://www.easo.org.tr/html/TUR/yayinlarimiz/ailesirketleri.pdf,

Birincioğlu, N. \& Acuner, T. (2016). Aile işletmeleri kurucularının ve aile değerlerinin aile işletmelerinin sürdürülebilirliği üzerindeki etkisi: Trabzon örneği. Uluslararası İktisadi ve İdari İncelemeler Dergisi, 14, 492-500.

Büte, M. (2010). Aile işletmelerinin kurumsallaşma sürecinde yaşadığı sorunlar. Akademik Bakış Dergisi, 22, 97-120.

Br1ley, S. (1986). Succession in the family firm: The inheritor's view. Journal of Small Business Management, 24(3), 36-43.

Cadbury Raporu. (1999). The financial aspects of corporate governance.

Caufman, L. (2001). Challenging the family business: The relational dimension, Oslo: Scandinavian. Journal of Organisational Psychology, 2, 53-62.

Chua, J. H., \& Chrisman, J. J. (1999). Sharma pramadita., defining the family business by behavior, entrepreneurship. Theory and Practice, 23(4), 19-39.

Daspit, J. J., Holt, D T., Chrısman, J. J., \& Long, R. G. (2016). Examining family firm succession from a social exchange perspective: A multiphase, multi-stakeholder review. Family Business Review, 29(1), 44-64.

Debarlıev, S., \& Janeska-Ilıev, A. (2015). Family business characteristics and differences: Some insights from the developing countries, in challenges of Europe: International Conference Proceedings, 39-60.

Deloıtte, Aile işletmeleri için adım adım kurumsal yönetim, 2007. http://www.tkyd.org/files/downloads/faaliyet_alanlari/yayinlarimiz/ tkyd_yayinlari/aile_sirketleri_icin_adim_adim_ky.pdf(E.T. 12.04.2019)

Den1s, J. (2018). If you want your family business to last several generations, Forbes.

https://www.forbes.com/sites/dennisjaffe/2018/08/30/if-you-want-your-family-business-to-last-several-generations/\#715173c07c16 (Erişim Tarihi: 30.06.2019)

Drucker, P. F. (2000). 21. yüzyıl. için yönetim tartışmaları (İ. Bahçıvangil, \& G. Gorbon,Çev., . 2.bs). İstanbul: Epilson.

Dyer G. W. (1986). Culturel change in family firms, anticipating and managing business and family transitions, Jossey-Bass Inc. Publishers, San Francisco.

Dyer, W. G. Jr. (1988). Culture and continuity in family firms. Family Business Review, 1(1), 37-50. 
Dyllıck, T., \& Hockerts, K. (2002). Beyond the business case for corporate sustainability. Business Strategy and the Environment, 11(2), 130-141.

Fındıkçı, İ. (2005). Aile işletmelerinde yönetim ve kurumsallaşma. İstanbul: Alfa Yayınları.

Fındıkçı, İ. (2014). ABD'de en büyük 500 firmanın üçte biri aile işletmesi. Erişim adresi: http://www.bloomberght.com/haberler/ haber/1534645-aile-sirketlerinde-surdurulebilirlik-ve-kurumsallasma

File, K. M. (1995). Is there a trillon dolar family business market? Industrial Marketing Management, 24, $247-255$.

Güleş, H. K., Arıcıoğlu, M. A., \& Erdirençelebi, M. (2013). Aile işletmeleri: Kurumsallaşma, sürdürülebilirlik, uyum. Ankara: Gazi Kitabevi.

Güney, S. (2008). Aile işletmelerinde güncel konu ve sorunlar (1.bs.). Ankara: Siyasal Kitabevi.

Güngör Ak, B. (2008). Aile işletmelerinin kurumsallaşmasında gelecek nesillerin eğitiminin rolü. 3. Aile İşletmeleri Kongresi, Kongre Kitabı. İstanbul: İstanbul Kültür Üniversitesi Yayınları.

Hodgetts, R. M., \& Kuratko, D. F. (1995). Effective small business management (5 ${ }^{\text {th }}$ eds.) Australia: Fort Worth Dryden Press.

Karpuzoğlu, E. (2004). Büyüyen ve gelişen aile işletmelerinde kurumsallaşma. İstanbul: Hayat Yayınları.

Kayalar, M. \& Özmutaf, M. N. (2007). Gelişme yönelimli kurum kültürü ile yöneticinin yönetsel tutumları arasındaki ilişkisellik: 100 büyük sanayi kuruluşunda bir araştırma. Süleyman Demirel Üniversitesi İktisadi ve İdari Bilimler Fakültesi Dergisi, 12(3), $163-176$.

Kenneth, K. (1996). When the family business is a sickness. Family Business Review, 9(4), 347-368.

KOSGEB. (2009). Aile işletmeleri: Avrupa birliğindeki yaklaşımlar. Erişim adresi: http://kosgeb.gov.tr/Paes/UI/UluslarArasilliskiler. aspx?refIn=33

Le Breton, I., M1ller, D., \& Steier, L. P. (2004). Toward an integrative model of effective FOB succession. Entrepreneurship Theory And Practice, 28(4), 305-328.

Norton J. (2019). Seven steps to sustainability in family business - A cautionary tale Ed.D., Family Business Consulting Group.

Olson, P. D., Zuiker, S. V. \& vd. (2003). The 1mpact of the family and business on family business sustainability. Journal of Business Venturing, 18, 642-644.

Oudah, M., Jabeen, F., \& Dixon, C. (2018). Determinants linked to family business sustainability in the UAE: An AHP approach. Sustainability, 10(1), 2018.

Prıcewaterhousecoopers. (2012). Aile işletmeleri: 21. Yüzyll'ın vazgeçilmez iş modeli, küresel aile işletmeleri araştırması 2012 Türkiye sonuçları. Erişim adresi: http://taider.org.tr/wp-content/uploads/2013/11/pwckuresel-aile-arastirmasi-2012-turkiye-sonuclari-kasim2012-fce8c.pdf

Schulze, W. G., Lubatkin, M. H., \& Dino, R. N. (2003). Exploring the agency consequences of ownership dispersion among the directors of private family firms. Academy of Management Journal, 46(2), 179-194.

Stafford K., Duncan Karen, A., Dane, S. \& Winter, M. (1999). A research model of sustainable family businesses. Family Business Review, 12(3), 197-208.

Strike, V. M. (2013). The most trusted advisor and the subtle advice process in family firms. Family Business Review, 26(3), $293-313$.

Şimşek, M. Ş. (1998). Yönetim ve organizasyon (4.bs). Konya: Eğitim Kitabevi.

Tagiurı, R., \& Davis, J. (1996). Bivalent attributes of the family firm. Family Business Review, 9(2), 199-208.

Tapıes J., \& Ceja L. (2011). Family protocol: Better to agree and put it in writing, IESE Insight.

Tricker, B. (2012). Corporate governance: Principles, policies and practices. 2. Edition, New York: Oxford University Press.

Ungerer, M., \& Mienie, C. (2018). A family business success map to enhance the sustainability of a multi-generational family business. International Journal of Family Business and Management Studies, 2(1), 1-13.

Venter E., Merwe S. V., \& Farrıngton S. (2012). The impact of selected stakeholders on family business continuity and family harmony. Southern African Business Review, 16(2), 69-96.

Ward, J. L. (2005). Unconventional wisdom: Counterintuitive insights for family business success, England, UK: John Wiley \& Sons Inc. 
Ward, J. L. (1997). Growing the family business: Special challenges and best practices. Family Business Review, 10, $323-338$.

Yelkikalan, N., \& Aydın, E. (2010). Aile işletmelerinin yaşamlarını sürdürebilmesinde sonraki kuşakların duygusal sahiplik algılamasının rolü ve önemi: Türkiye'deki kıdemli işletmeler üzerine bir araştırma. Yönetim Bilimleri Dergisi, 8(2), 81-120. 